\title{
LAZER: O DIREITO À PREGUIÇA RESSURGENTE'
}

\author{
Carlos Alberto Braile \\ Curso de Especialização em Sociologia e \\ Sociologia da Educação da Universidade Estadual de Londrina
}

\section{Resumo}

O estudo do lazer, neste artigo, visa investigar conceitualmente este fenômeno social em plena evidência que, cada vez mais, se torna objeto de uso e de costume. Além disso, em razão das mudanças que o lazer vem sofrendo, especialmente nestes últimos anos, muitos estudos o colocam como ponto culminante de transição rumo ao novo milênio. Do pontọ de vista econômico o lazer é o segmento que mais cresce no mundo e, devido à sua complexidade e por suas potencialidades, está propiciando uma das maiores transformações sociais já vividas ao longo da história.

Palarras-chave: trabalho: lazer; revolução industrial.

ecreação, distração, passatempo, ócio, tempo livre, atividade lúdica, descanso, jogo, folga, não-trabalho, devaneio, divertimento, recreio, hobby, fruição, gozo, folguedo, brincadeira, desfrute, descontração, eis alguns dos diferentes termos que pretendem indicar ou designar este fenômeno que hoje, mais do que nunca, interfere na vida das sociedades modernas.

Esta manifestação social, tão inserida na vida cotidiana, especialmente daqueles que vivem nos grandes centros, tem sido motivo de atenção e destaque nos mais diferentes segmentos do conhecimento humano da atualidade. E não são poucos os motivos que têm levado o lazer a ser objeto de toda essa propalada e recente preocupação. $\mathrm{Na}$

O texto é uma adaptação da monografia de mesmo titulo apresentada ao Curso de Especialização em Sociologia e Sociologia da Educação, da UEL, em Abril de 1.999. sob orientação do Prof. Ronaldo Baltar. 
economia, na política, na filosofia, na moral, na psicologia, na biologia, na arquitetura, na botânica, no jornalismo, em meios aos pesquisadores de mercado, junto aos religiosos, no direito e ainda mais diretamente em nosso campo de estudos, na Sociologia, observa-se uma dedicação cada vez maior dos pesquisadores a esse tema. Os desdobramentos que o lazer vem imprimindo, suas causas e seus efeitos, afetam a cada momento não só o ritmo daqueles que dele se utilizam, como também daqueles que dele se ocupam.

Fonte de prazer e diversão, e também de alienação e estranhamento, o lazer é ao mesmo tempo fonte de trabalho e riqueza e suas ações afetam os mais diferentes segmentos da sociedade, mudando hábitos, reformulando costumes e desencadeando uma crescente revolução sociocultural.

A sociedade, direta ou indiretamente, é atingida por essa grande novidade, ainda que não dê conta disso. Assim, sem se aperceber adequadamente seu envolvimento, não se consegue refletir e, portanto, agir ou reagir de forma compatível.

Este trabalho tem essa pretensão, ou talvez mais do que isso, tem o objetivo de desencadear um processo de alarme, para que as pessoas se dêem conta de que algo inusitado está ocorrendo na sociedade neste final de milênio, permeando mais do que nunca sua vida, não só alterando hábitos ou costumes, mas, como decorrência disso, impondo novos valores, e portanto, estabelecendo uma nova ética social.

Neste artigo será exposto um roteiro simples, mas objetivo, que irá tratar, ainda que de forma não profunda, alguns aspectos básicos e indicativos desse ainda desconhecido fenômeno social chamado lazer: Quem sabe, conhecendo, compreendendo e assimilando um pouco mais sobre sua gênese, seus diferentes aspectos, seus conceitos suas dimensões e suas perspectivas, se possa não só mudar a visão existente em torno do lazer, como também interpretá-lo, incorporá-lo, e vivenciá-lo convenientemente, quer no âmbito pessoal, quer no âmbito comunitário.

Tão antigo quanto o próprio trabalho, o lazer acompanha o homem em sua trajetória pela história, sem que, muitas vezes ele, se dê conta dessa doce companhia. Desejamos neste artigo percorrer muito rapidamente esta trajetória, com o ânimo de quem desfruta do lazer nestes conturbados dias de hoje, sabendo que ele tem que ser conquistado 
a duras penas, constituindo-se muitas vezes uma utopia, que nem sempre se alcança totalmente, mas que eventualmente propicia descanso e prazer, além de estar provocando uma das maiores revoluções culturais na sociedade hodierna.

\section{Lazer: fenômeno social sempre presente}

A luta pela sobrevivência, a necessidade de dominar a natureza para dela dispor, levou o homem desde os primórdios ao trabalho. A relação entre existir e trabalhar sempre acompanhou a humanidade em todos os seus passos, mesmo quando gerada pelas mais diversas contingências ou imposições. Mas, sempre envolto nessa relação entre trabalho e sobrevivência estava presente o descanso, a festa, o jogo, o repouso, enfim, um tempo que escapava ao ato exclusivo da produção ou da manufatura, entretenimentos esses às vezes bem notáveis, mas muitas vezes tão misturados ao trabalho, que quase não podiam ser percebidos ou distinguidos. O que veremos a seguir é um pouco da investigação e da identificação da existência do tempo livre na nossa história da humanidade.

\section{Voltando um pouco no tempo}

Muito embora observações mais rigorosas tenham sido feitas só há bem pouco tempo, o lazer foi um agente influenciador do desenvolvimento social da humanidade. É lícito, pois, argumentar que ele sempre fez parte da vida social do homem, ainda que sua marcante presença nunca tenha sido devida e convenientemente destacada. Isso, na verdade, somente passou a ocorrer por força das conquistas resultantes das reivindicações contrárias, nos longos e extenuantes períodos de trabalho, ocorridas muito recentemente. Assim, desse ponto de vista, podemos considerar o lazer como um produto originado da sociedade industrial, que, enquanto lutava por diminuir as horas de trabalho, utilizava-as gradativamente como tempo de lazer, com características próprias de sua época, e condizentes com sua estrutura sociocultural. 
A importância do tempo fora do trabalho é algo tão antigo como o próprio trabalho em si. No entanto, o lazer, na sua forma moderna, possui uma especificação peculiar, caracterizada especialmente pelos traços da civilização gerada na pós-revolução industrial. Este lazer é visto por parte dos sociólogos interessados pelo assunto, como algo novo, recente, com fortes sinais dos tempos atuais.

Nas sociedades menos estruturadas, a maioria das pessoas trabalhava tão arduamente para manter-se, assim como às suas famúlias, que eram realmente privadas de lazer, entenda-se, da forma como o lazer é visto e compreendido em suas concepções atuais. Para a maioria delas, não passava de mero intervalo do trabalho, e não raro voltado para atividades estereotipadas, em geral nos rituais religiosos ou cerimoniais.

Nessas sociedades mais simples, não se tinha como traçar limites divisores entre tempo de trabalho e tempo de lazer. "Os povos primitivos tendem a dar a muitas de suas atividades cotidianas um caráter lúdico.", de acordo com Parker (1978, p.24). Os antropólogos que estudam essas sociedades mais simples registram um padrão muito interligado e integrado entre lazer e trabalho, bem diferente do que ocorre nas sociedades industriais modernas. Naquelas sociedades não existiam jornadas ou momentos de lazer definidos como tais, e certas atividades como a caça, a pesca ou a ida a um centro de compras distante, acabavam por incorporar um caráter de divertimento e, portanto, confundido com lazer. Algumas dessas sociedades, quando mesclavam atividades como o canto ou os contos (transmissão da história oral) à construção de uma habitação comunitária, por exemplo, criavam naturalmente o trabalho - divertimento, não estabelecendo separação entre tempo de trabalho e tempo de descanso ou distração.

Os ritos de iniciação, de passagem ou de perda, interligando o cotidiano com a religião, ou as festas vinculadas aos fenômenos climáticos ou às épocas de plantio ou colheita, eram momentos que entremeavam rotina de trabalho com manifestações não laboriosas, impossíveis de serem distinguidas.

Para os romanos a questão do OTIUM e do NEG-OTIUM (DUMAZEDIER, 1974, p. 19) era motivo de grandes debates da alta classe dirigente da sociedade, dando margem a discussões que se incorporaram à moral e consequentemente ao direito romano e às grandes 
manifestações das conquistas bélicas de então. Mesmo ligado singularmente ao aparato bélico que influenciava a cultura da Roma antiga, o lazer sempre esteve presente na sociedade romana, principalmente nas suas manifestações de caráter lúdico. No pensamento dos filósofos da antiga Grécia, especialmente no de Aristóteles e Platão, lazer era algo mais do que tempo livre. Para eles, o lazer se baseava numa associação de aprendizagem, ou cultivo do eu, portanto agregava e in-

corporava elementos intelectuais além do tempo livre. Para os gregos, o contrário de lazer não se fazia apenas com trabalho.

"Percebe-se um elemento diferente, um tom ético, uma insinuação de que o tempo livre malbaratado, não é lazer... O lazer é uma condição ou um estado de estar livre da necessidade do trabalho." (DEGRAZIA apud PARKER (1978, p.26).

Redescoberta no século XIII, a filosofia grega vem tomar conta do pensamento humano da Idade Média e dar novos rumos não só às artes e às ciências, mas a todo o comportamento social vigente. Paul Lafargue também usa o antigo pensamento da clássica Grécia para fundamentar sua argumentação no final do século XIX e oferece-nos a seguinte contribuição:

"Os gregos da época áurea desprezavam igualmente o trabalho: o homem livre só conhecia os exercícios corporais e os jogos da inteligência. Era também o tempo em que se caminhava e respirava num povo de Aristóteles, Fídeas, e Aristófanes; (...) os filósofos da antigüidade ensinavam o desprezo pelo trabalho, essa degradação do homem livre." (LAFARGUE, 1977, p.13).

Sem nos aprofundarmos no contexto filosófico que envolve o conceito grego de lazer, ou seja, o lazer ideal, temos que admitir que ele foge à análise geral que se observa a respeito desse assunto, visto que a sociedade grega baseava-se no trabalho escravo e, portanto, o lazer só podia ser apropriado aos homens livres.

Faz-se mister registrar, no entanto, que têm origem no mundo da clássica sociedade grega os jogos olímpicos, nascidos da prática da educação voltada aos exercícios de guerra, pela classe privilegiada. Nos espaços denominados ginásios ou estádios já se praticavam conridas a 
pé, lutas corporais, várias modalidades de atletismo, a par do que já ocorria nas chamadas academias, onde se desenvolviam atividades intelectuais e estéticas, enquanto que nas praças se estimulava o debate público e os banhos também públicos, disponibilizados como forma de repouso e divertimento. Portanto, tornar o lazer acessível a todos já era uma preocupação que, mesmo partindo de princípios diferentes e com objetivos também diferentes, delineava desde então a percepção de que esta atividade social trazia consigo, subjacente, uma necessidade inerente ao ser humano.

O tempo livre do trabalhador não-escravo era de fato muito maior do que o trabalhador de hoje e bem maior do que o trabalhador do fim do século XVIII, quando a Revolução Industrial teve início. Anteriormente a ela, a cada três dias o trabalho se interrompia, para um dia de descanso ou uma espécie de feriado. A partir do fim da Idade Média, o número de horas de trabalho foi gradativamente crescendo até alcançar seu limite máximo por volta de 1800 . Foi nessa época, quando o trabalho passou a ser exercido em espaços físicos especiais, durante um período de tempo específico e sob condições e regras ordenadas, cada vez mais circunscrito em centros urbanos de maior densidade populacional, é que o lazer começou a ser exigido como direito.

Não é por menos que o ponto referencial, a partir do qual o lazer passou a ser considerado como fenômeno social, digno das mais relevantes considerações, é a Revolução Industrial. Tomando forma no final do século XVIII e consolidado durante o século XIX, esse grande marco da história, ao gerar uma sociedade industrial, com um estatuto social característico, acabou por instituir, embora como subproduto, o lazer. A revolução que inicialmente enfocou o trabalho trouxe como consequiência as primeiras regulamentações do lazer. O tempo liberado pela redução do trabalho industrial criou o lazer, sinônimo desse dito tempo liberado.

O lazer é, por assim dizer, uma conquista adquirida pelas lutas proletárias contra as longas jornadas de trabalho, a partir do nascimento das casas industriais. As crescentes reduções das longas horas de trabalho, até a grande conquista da instauração da jornada de oito horas, no inicio do século XX, forjaram as características mais fortes e mais atuais do conceito e das nuanças que designam o lazer, tal qual ele pode ser visto na atualidade. "Quando Karl Marx englobava o repouso na 
'reprodução da força do trabalho', não existia ainda lei que limitava em doze horas a duração da jornada de trabalho industrial.", (DUMAZEDIER, 1976, p.21). A duração do trabalho industrial numa semana daquela época era em média de treze horas diárias sendo mantidos os dias feriados e diminuídos os dias santos, compensado no aumento dos dias de férias, então regulamentadas.

Um cálculo bem simples nos dá conta de que, ao considerarmos que uma semana de trabalho nos dias de hoje não ultrapassa quarenta e quatro horas, o trabalhador atual passou a ter trinta e uma horas de tempo livre a mais por semana. Significa dizer que em pouco mais de cem anos, o trabalhador passou a ter mil setecentos e doze horas a mais de tempo livre por ano.

A novidade das férias anuais é uma realização que surgiu no século XIX, como evolução e adaptação das antigas semanas de folga, na verdade negociadas em troca da assiduidade regular ao trabalho. É o tempo livre constituindo-se como direito e, mais do que isso, como tempo não mais misturado com o trabalho. Ao contrário do lazer dos tempos medievais, justificado por algum tipo de rito ou celebração religiosa, um novo lazer da classe proletária impõe regras sociais novas, vai modificando a cultura, e faz nascer uma nova indústria, a do divertimento. A sociedade industrial gera e da à luz o lazer, com os traços que ele tem hoje como produto de consumo.

\section{Mas, o que é lazer?}

É bastante complexa a tentativa de definir o que seja o lazer. Como ele atinge pessoas de diferentes idades, de diferentes grupos sociais e ocupacionais, em diferentes localidades e de diferentes características pessoais, torna-se quase impossível apresentá-lo ou representá-lo de forma padronizada, que consiga expressar todas as variáveis que o compõe, ou todos os objetivos que ele possa alcançar. Além do mais, todas as vezes que as ciências conceituam um fenômeno, em geral acabam limitando ou deixando de fora algo importante a respeito. No entanto, nossa tarefa, a seguir, é apontar diversos indicativos que contribuem para a identificação e consequiente melhor 
compreensão do lazer, visto de distintos prismas e de diferentes pontos de vista.

Trabalhando, nesse sentido, PARKER (1978, p.13), em sua obra A Sociologia do Lazer questiona o seguinte:

"É realmente possível medir o lazer ? Os críticos talvez argumentem que o lazer não tem qualquer método-padrão de medida e que tais tentativas podem, na verdade, estar medindo outra coisa. Se o lazer for concebido enquanto experiência do indivíduo, é difícil aplicar qualquer definição padrão para propósitos de medida. Mesmo com o lazer concebido residualmente como tempo livre, o problema não se resolve. A própria idéia de tempo livre é enganosamente simplista e como observa Berger, se a sociologia nos ensinou alguma coisa, foi que tempo algum é livre de coações normativas; o que é trabalho para alguns, é lazer para outros."

Não obstante, encontramos algumas apreciações desenvolvidas por diferentes estudiosos do assunto, que muito nos ajudam a concentrar informações, para conceituarmos lazer de forma bastante satisfatória.

Uma dessas formas por exclusão, ou seja, eliminando das vinte e quatro horas do dia os períodos não utilizados para o trabalho e outras necessidades. Se subtrairmos trabalho, alimentação, necessidades fisiológicas, sono, por exemplo, vamos chegar ao resultado buscado. Corremos aqui o risco de não poder identificar adequadamente os fatores, pois cada um deles provoca divergências de avaliação, como, por exemplo: o sono fora da hora específica, não pode ser lazer? Uma refeição em ambiente familiar ou não, em tom amistoso e festivo, mesmo sendo no intervalo de trabalho, não poderia ser interpretada como lazer, ao invés de satisfação de necessidade fisiológica pura e simples? Esta definição, dita "residual", nos ajuda, mas é incompleta, e pode ser assim resumida: lazer é o tempo de vinte e quatro horas, reduzido do tempo gasto com o trabalho, com sono e outras necessidades.

Um outro tipo de definição sobre o lazer leva em conta o aspecto qualidade da atividade exercida, relacionando-a a uma visão filosófica ou religiosa, como observa Josef Pieper, que concebe o lazer, "como uma atitude mental e espiritual - não é simplesmente o resultado de fatores externos, não é o resultado inevitável do tempo de folga, ou 
feriado, um fim de semana ou um período de férias. É ... uma atitude do espirito, uma condição da alma.", (PIEPER apud PARKER 1978, p.20).

A combinação das duas formas acima, que podemos dizer ser o resultado do componente da forma "residual", com uma afirmativa "normativa", nos dá um terceiro conceito do lazer, que pode ser ilustrado com dois exemplos:

"O lazer é o tempo de que o indivíduo dispõe, livre de trabalho e de outros deveres,e que pode ser utilizado para fins de repouso, divertimento, atividades sociais ou aprimoramento pessoal", (GIST \& FNA apud). Ou, "é uma série de ocupações com as quais o indivíduo pode comprazer-se de livre e espontânea vontade - quer para descansar, divertir-se, enriquecer seus conhecimentos ou aprimorar suas habilidades desinteressadamente, quer para aumentar sua participação voluntária na vida da comunidade, após cumprir seus deveres profissionais, familiares e sociais." (DUMAZEDIER apud PARKER, 1978, p.21).

O lazer também pode ser considerado do ponto de vista de suas funçôes, como acredita o sociólogo francês Joffre Dumazedier, quais sejam: o repouso, o divertimento ou recreação e o enriquecimento dos conhecimentos e de participação social. Na primeira função, o homem tem a recuperação de seus esforços cotidianos; a segunda função lhe assegura o passatempo contra o tédio; e a terceira função lhe oferece estímulo ao desenvolvimento de sua personalidade.

Uma outra lente por onde também se pode ver o lazer á vista como a antítese do trabalho. Tudo, ou boa parte do que não é trabalho pode ser lazer. Mas essa é uma visão distorcida, que remete à também distorcila interpretação que se faz da palavra ócio, muitas vezes usada inadvertidamente, como contrário de trabalho.

Contudo, caso a palavra ócio ou ociosidade esteja sendo usada na sua conotação pejorativa, nesse caso sim tem-se a negação do trabalho, ao passo que o lazer efetivamente supõe o trabalho. Para DUMAZEDIER (1974, p.29): "lazer não é ociosidade, não suprime o trabalho; o pressupõe. Corresponde a uma liberação periódica do trabalho no fim do dia, da semana, do ano ou da vida de trabalho".

O que dizer, então, a respeito da possível confusão entre lazer e trabalho? Em que circunstâncias estas duas atividades, por assim dizer 
antagônicas, podem ser a mesma coisa ou coisas parecidas? Como iremos responder a esta questão ao nos deparamos com os artistas, os artesãos, atletas, jogadores, alguns empresários da moda ou do show biz, alguns executivos ou consultores? Da mesma forma não podemos dizer que tempo livre seja lazer. Todo lazer é tempo livre mas nem todo tempo livre é lazer. Estar desempregado é, em geral, ficar com bastante tempo livre, mas não significa dizer que pessoas sem emprego, assim como aquelas que se aposentam com poucos rendimentos, estejam desfrutando de um tempo de gozo. Muito pelo contrário.

$\mathrm{Na}$ verdade, todo estudo sociológico voltado para observar o lazer tomou corpo quando este se desatou do trabalho, na medida em que o trabalho passou claramente a ser mão-de-obra vendida ao dono do capital. Enquanto o homem pré-industrial compunha sua existência como proprietário de sua vida como um todo, a instituição trabalho e a instituição lazer não eram configuradas como o são hoje em dia, e à medida que o trabalho vem sofrendo grandes transformações em sua base conceitual e ideológica, o lazer igualmente vai se reconfigurando e se reconceituando automaticamente. Por ora, já temos algumas informações fundamentais.

Segundo a explicação de CAMARGO (1977, p.18), "lazer é sempre um fazer-alguma-coisa. Contudo, como fica essa ação de não se fazer absolutamente nada, que a cultura italiana tão saborosamente designou de dolce far niente? É impossível não se fazer absolutamente nada. O devaneio é uma ação muito significativa. Os psicoterapeutas que o digam. Deixar-se levar, a si, e às sensações, deitado numa rede, é um momento de rara inventividade no reencontro de si mesmo. Poucos, aliás, o conseguem na plenitude, despindo-se dos problemas e das preocupações, e entregando-se à riqueza do momento presente".

Vamos agora tentar focalizar o lazer do ponto de vista de suas propriedades e de suas funções.

Em meio a sua imensa dedicação ao estudo da sociologia do lazer, DUMAZEDIER (1974, p.93) entendeu denominar lazer toda atividade que apresentasse as quatro seguintes propriedades. Segundo sua ótica, "duas de caráter negativo, que advêm das obrigações impostas pelas instituições de base da sociedade, e duas outras positivas intimamente ligadas às necessidades da personalidade de cada indivíduo". 
São elas:

$\left.1^{\circ}\right)$ De caráter liberatório, que se tem quando o lazer é resultado de uma escolha livre, desvinculado do que se conhece como obrigações institucionais, na medida em que são impostas por organismos sociais, como empresa, família, religião, partido político, entre outros;

$2^{\circ}$ ) De caráter desinteressado: que se tem quando o lazer não pressupõe fim lucrativo, como o trabalho, ou fim utilitário, como os deveres domésticos ou fim ideológico, como as obrigações religiosas ou políticas;

$\left.3^{\circ}\right)$ De caráter hedonístico: tem-se quando o lazer visa obter satisfação, prazer, alegria, que são traços marcantes dos anseios da sociedade moderna;

$4^{\circ}$ ) De caráter pessoal: tem-se quando as funções objetivadas pelos seus interesses são uma resposta às necessidades individuais do sujeito.

Assimilando as características acima mencionadas, podemos orientar-nos para a seguinte definição do lazer: lazer é: toda e qualquer atividade desinteressada, liberatória, nascida de uma escolha pessoal na busca de satisfação ou prazer.

Dizer o que é lazer pressupõe um exame de sua gênese e uma investigação de seus diversos componentes. Implica também acompanhar sua evolução e suas constantes modificações e reformulações, além de observar suas implicações como agente de mudanças culturais, sociais e éticas, sobre isso que iremos discorrer mais pelo final deste artigo.

Mas, além de alguns de seus componentes já vistos neste tópico, é importante assinalar algumas questões que compõem o lazer, especialmente a partir da civilização industrial.

Foi a industrialização que modificou o antigo ritmo de trabalho, ditado pelas estações climáticas e paralisado por aocasião dos rituais, festas e jogos. Surgem a partir dessa metamorfose radical, as primeiras intervenções dos pensadores daquela época. No pensamento de Marx, o repouso era visto como a reprodução da força de trabalho. Uma 
observação mais atenta do significado da palavra recreação pode levar- nos a entender este pensamento. Em seu sentido literal, recreação remete à renovação, revigoramento, reabastecimento para a retomada de novo período de trabalho.

Nessa direção, Marx (apud DUMAZEDIER,1976, p.29), acentua que lazer é:

"O espaço que possibilita o desenvolvimento humano; para Proudhon é o tempo que permite as "composições livres": para Augusto Comte é a possibilidade de desenvolver a "astronomia popular," etc. Engels, enfim, pedia a diminuição das horas de trabalho "a fim de que todos tivessem tempo suficiente para participar dos negócios gerais da sociedade”. Essa identificação entre lazer e a instrução popular parece ser ainda familiar à sociologia soviética contemporânea e, na França, ela reflete uma das tendências da 'educação permanente'."

Para os sociólogos norte-americanos a visão de lazer ficou um pouco reduzida à análise das diferentes formas de recreação, ou seja, lazer é uma atividade livre, não paga e que oferece um prazer imediato. Já, AUGÉ, fundador da Enciclopédia Larousse, explica o lazer como: "distrações, ocupações às quais podemos nos entregar de expontânea vontade, durante o tempo não ocupado pelo trabalho comum". (AUGÉ apud DUMAZEDIER, 1976. p.30).

Certamente todos estes indicativos não nos satisfazem e, por conseguinte não encerram a questão, o que nos leva, enfim, para as pesquisas que analisam o lazer conforme sua classificação ou suas categorias. Mas como elas não atendem ao escopo que desejamos dar a este artigo, neste momento limitar-nos-emos a apresentar somente uma delas elaborada de um estudo de HAVIG HURST, em Kansas City, no ano de 1955.
1) participação em grupos organizados;
2) participação em grupos não organizados;
3) viagem de recreação;
4) participação nas atividades esportivas;
5) assistência a espetáculos esportivos (não incluindo TV);
6) televisão e rádio; 
7) caça e pesca;

8) "jardinagem"(flores, legumes e passeios no campo);

9) trabalhos manuais (costura, marcenaria, bricolage);

10) atividades de imaginação (leitura, música, arte);

11) visitas a parentes e amigos (HAVIG HURST apud DUMAZEDIER, 1974, p.99).

\section{O lazer na modernidade: a composição de um novo homem.}

Já tivemos oportunidade de observar que nem todo tempo livre é lazer: Há, pois, além do lazer, um novo tempo a ser levado em conta, o qual podemos denominar de "tempo inocupado", caracterizado pelo desemprego, sub-desemprego ou inatividade, decorrente de uma aposentadoria precoce ou mal-remunerada. As instituições de base da sociedade, esteriotipadas nos agrupamentos familiares, profissionais, espirituais e sócio-políticas, nos dão os tempos que podemos chamar de "tempo obrigado" (trabalho profissional, escolar e familiar) e "tempo compromissado", (vida sócio espiritual e vida sócio política), conforme sugere Joffre Dumazedier.

Queremos com essa dita "classificação" dos tempos registrar o quanto o lazer, desempenha na sociedade moderna, um papel nunca tão considerado, como na atualidade. Até bem pouco tempo, o dia de vinte e quatro horas era dividido em três grandes partes iguais e, portanto, se tornava extremamente simples e rápido tratar sobre o tema lazer, partindo apenas da observação e eliminação daquilo que ele não é. Ou seja, tudo que não é social, nem trabalho, é lazer. Mas, na verdade, se não sabemos, ao menos intuímos, que lazer nos dias de hoje é algo mais amplo e significativo, além de mais complexo, do que essa simples conclusão. Eé justamente essa complexidade que nos leva a identificar que uma nova espécie humana está sendo gerada, nascida após o surgimento do lazer na sociedade moderna.

Seguindo as pistas de Joffre Dumazedier em sua obra Lazer e Cultura Popular, podemos afirmar que o século XX produziu um novo "homem imaginário", fruto da influência do lazer na vida moderna. 
O tempo livre, ordenado, resultante de uma nova forma de vida, ditada pelas regras do trabalho industrial, possibilitou à sociedade novas opções de ocupação, adaptadas, ou ao alcance das diferentes classes sociais. "Com o desenvolvimento do lazer, surgiu uma procura crescente de obras de ficção que pôde ser satisfeita, depois da descoberta da imprensa, dos sons e das imagens com movimento" (DUMAZEDIER 1976, p.41). O que se viu a partir do final do século XIX até nossos dias foi, sem dúvida, uma enorme busca pela leituraem todos os seus níveis de qualidade- pelo cinema e mais recentemente pela televisão, no espaço liberado para o lazer, favorecendo como nunca antes, a formação desse novo homem voltado e preparado para o imaginário. A escola, ou seja, a cultura sistemática, assim como as ideologias propostas à sociedade desses últimos tempos não deram conta de oferecer ao homem produzido neste mesmo espaço de tempo alternativas mais atrativas para alimentar convenientemente seu imaginário. A concorrência tornou-se forte e praticamente insustentáveis.

Mas o reverso da medalha oferece pontos positivos, porquanto o tempo livre não utilizado apenas para o entretenimento, para a distração ou para a simples recreação, foi demasiadamente bem canalizado para a formação desinteressada. A procura pela leitura, num primeiro momento, e, a seguir, pelo televisor, cinema e outras opções de informação, mesmo que não técnicas, na maior parte das vezes, passou a formar uma geração de pessoas com tendência a uma melhor formação cultural. Um novo contingente autodidata se formou neste século, levado pelo interesse por informações sobre trabalho, cultura geral, questões sócio econômicas e políticas, programas técnico/científicos, e treinamento profissional. Como diz DUMAZEDIER (1976, p.43): "além de um novo homem imaginário forma-se um novo Homo sapiens".

Igualmente, nasce um novo homo socius, gerado pelo surgimento do lazer, que possibilita novas formas de vida social e sociabilidade, até então desconhecidas. O que hoje chamamos happy-hour é invenção começada a partir do excedente de tempo após o trabalho. A procura pelo bar e outras formas análogas de distração surgiu e se consagrou após o aumento do tempo lazer, no pós-trabalho, notadamente no início 
do século XX. Hoje são os cafés, os pubs, as casas de sucos e aperitivos, de sinuca ou de bingos, que tomam conta do tempo vago, após o tempo gasto com o trabalho.

"No entanto, são as informações recreativas e educativas a forma mais original de sociabilidade desenvolvida pelo lazer"(DUMAZEDIER 1976, p.47), já que não decorrem de nenhuma ligação com as necessidades de trabalho, como o são os sindicatos ou associações profissionais, e outras ligadas às práticas políticas ou religiosas, sejam partidos ou organizações confessionais.

Olhando, agora, o homem através de sua face lúdica, iremos perceber que é também por este viés que um novo homem foi reinventado.

Até meados do século passado, a cultura dos operários ainda estava profundamente marcada pelas festas e jogos tradicionais, religiosos e corporativos. No entanto, o que se vê nos dias de hoje é a total emancipação das competições e das festas em relação a qualquer ritual ou cerimônia.

Jogos, disputas, concursos, shows e festas, motivadas, pelas mais inusitadas ou estapafúrdias razões, enfim uma variedade sem fim de diversões coletivas, são postas à disposição do mundo moderno, para que a sociedade extravase sua face lúdica. Há registro de maior ou menor incidência delas por classes sociais. Populares ou elitizadas, com orçamentos astronômicos ou modestos, com patrocínios poderosos ou não, com a presença de pop-stars ou artistas não consagrados, eventos de toda ordem levam multidões a se divertirem em casas especializadas, ou em espaços públicos, ou em ambientes improvisados com apresentações gratuitas, ou pagas a peso de ouro.

O esporte de um lado, os jogos de azar, do outro, os mega-shows, e o turismo de uma forma dirigida ou independente, entre tantas outras atrações, descaracterizadas de qualquer vínculo com as já mencionadas instituições de base da sociedade, são hoje os veículos, pelos quais o homem moderno manifesta sua propensão para o lúdico.

Este homem não joga ou festeja apenas porque carrega consigo a eterna criança dentro de si. "O jogo não é somente, como dizia Freud, uma reminiscência do universo infantil, mas se tornou uma exigência da cultura popular nascida do lazer" (DUMAZEDIER, 1976, p.40). Assim, a nova sociedade nascida com o lazer revela o novo homo ludens. 
Mas, não é só caracterizado como por um novo homo ludens, um novo homo sapiens, um novo homo socius, e novo homem imaginário, que este ser híbrido, resultante da hodierna genética do lazer é composto. Um novo homo faber foi gerado na mixórdia com os demais Homo acima referidos.

Quem sabe por motivos psicológicos, talvez por questões econômicas, "independente do trabalho profissional complementar, verifica-se uma crescente expansão de atividades manuais, em parte desinteressadas, em parte utilitárias, quer no local do trabalho, quer no jardim da família." (DUMAZEDIER, 1976, p.36). Em outras palavras, independente de ocupações exercidas voluntariamente como uma segunda profissão, homens e mulheres, praticam, cada um a seu modo, nos mais diversos horários ou locais, uma infinidade de afazeres normais fora do trabalho, que em proporções variáveis se mostram utilitários e desinteressados, ou um misto de ambas.

Estes "semilazeres", como também são denominados, podem incluir os trabalhos manuais conhecidos como os tricôs, os bordados, a jardinagem, os mais diferentes artesanatos, os quebra-cabeças, os modelismos (aero, nauti, auto, etc.) e os trabalhos de reparos ou instalações de equipamentos em residências e escritórios. Lojas especializadas se incumbem, atualmente, de compensar o caráter rudimentar dos instrumentais e processos primitivos dessas práticas. Devolve-se, destarte, ao homem de hoje a possibilidade de utilizar sua criatividade original, castrada pela monotonia da vida industrial ou administrativa.

Identificada ainda como pertencente à geração do "faça você mesmo" (do it yourself), esta categoria de trabalho artesanal é uma antítese e até mesmo uma reação contrária à civilização forçada à divisão racional do trabalho, restituindo ao trabalhador a possibilidade de retorno às origens, quando todos os bens necessários à subsistência humana provinham das múltiplas habilidades de um só homem ou de um pequeno grupo.

A "bricolagem", designação pela qual esta atividade produtiva, não-profissional, é também reconhecida, tem merecido, da sociedade contemporânea, não só lojas e revistas especializadas para o atendimento dirigido ao seu aficionado público consumidor, como igualmente feiras, reuniões e congressos, planejados especificadamente para este fim. 


\section{Sinal dos tempos}

Uma grande expectativa se forma em torno do lazer, enquanto ele é visto como uma nova fonte de empregos, uma espécie de tábua de salvação do modelo neo-liberal desse final de século. Indústria sem chaminés, o lazer acolhe a mão-de-obra excluída das fábricas, reciclada para o mundo dos serviços. Grande parte do contingente desempregado do setor secundário, tende aos poucos a se adaptar a esse novo mercado de trabalho, que cresce na proporção inversa da indústria.

Mas, será que é só neste eixo, o econômico, que o lazer acarreta mudanças? A indagação merece uma avaliação menos superficial, já que a fenda aberta deixa à mostra outros indicativos subjacentes, que nos obrigam a uma prospeção mais cuidadosa e demorada.

Há um mal-estar generalizado, não só no trabalho, como na escola e na família. Drogas, desemprego, aposentadoria precoce ou compulsória são sinais de que o tédio nunca ocupou espaços tão largos como na atualidade. Em contrapartida, a capacidade humana nunca foi capaz de propiciar tanta tecnologia e saúde à sociedade e nunca se viu, em toda história, um tempo com tanto mal-estar em contraste a tanto bem-estar.

Como veremos com mais propriedade adiante, na conclusão desse trabalho, em que pese todo know-how e criatividade aptos a otimizar a produtividade industrial, o tempo livre gerado como excedente é proporcionalmente insignificante, e consequentemente frustrante.

Mas, o que a realidade mostra é que o lazer, independentemente de realizar o homem, ou não, cresce e se apresenta como um fenômeno em metamorfose, arrastando consigo toda a sociedade, e portanto modificando-a, enquanto é modificado por ela num ciclo constante.

Na introdução de seu livro, A Revolução Cultural do Tempo Livre, Joffre Dumazedier já aponta esta metamorfose, e no decorrer de toda essa sua obra, faz uma análise minuciosa e preciosa a respeito. Segundo ele, o lazer está provocando a maior revolução cultural deste fim de século e de milênio, uma revolução atípica, contrária aos moldes das revoluções dos tempos passados, sinônimo de luta armada, associada à ideologias políticas, levadas a efeito com ferocidade, barulho, sangue, vingança e muitas vezes seguidas de conquistas efêmeras e inconsistentes. Bem diferente, no entanto, é esta revolução a que se 
refere o eminente sociólogo francês, ao tratá-la como um movimento pacífico, silencioso, secreto, imperceptível e apolítico que progride a passos lentos, porém firmes e seguros.

Este século foi pródigo em revoluções semelhantes. A prática frequiente do exercício físico, nas academias, nos parques públicos, nos condomínios, para mulheres e homens, de todas as idades, criou a revolução do corpo. A estabilidade da legislação trabalhista voltada para o empregado gerou a revolução das férias. Quando a prática sexual se desvinculou da obrigatoriedade da reprodução da espécie e os mecanismos contraceptivos se popularizaram, falou-se em revolução sexual. Quando a sociedade se viu intimidada pela ameaça do tudo-pronto, emergiu a revolução do faça-isso-você-mesmo (do it yourself). E assim como essas, outras tantas transformações, na religião, na escola, na cultura popular, por exemplo, ocorreram invertendo ou subvertendo o cenário social desses últimos tempos.

Mas, o que nos importa assinalar é um pouco do que permanece oculto, por trás dessas transmutações, motivo dos comentários que faremos na seqüência.

\section{0 despertar de uma nova ética social}

"Cada um de nós sente confusamente que estamos mergulhados em uma época de longa transição. Os valores mais estabelecidos de nossa civilização tremem." (DUMAZEDIER, 1994, p.22). E todo tremor gera em primeiro lugar medo, e insegurança. Já num segundo momento, independentemente das consequiências do tremor vem a avaliação, a busca de explicações, o entendimento. As proposições originais sempre trazem consigo o incômodo inicial, seguido da assimilação mais ou menos demorada.

A modernidade trouxe em seu rastro a industrialização, e a divisão racional do trabalho e, como sub-produtos, uma infinidade de quebras de paradigmas e de valores, recriando-os em seguida, devidamente adaptados às realidades vigentes.

Um desses paradigmas, demasiadamente abatidos pelo corrosivo ataque das transições contemporâneas é o trabalho. O baluarte 
marxiano que o coloca como a "primeira necessidade do homem", já não se sente tão à vontade, como uma fortaleza inexpugnável. E, se conceitualmente o trabalho já não é mais focado em seus dogmas tão ortodoxos, a realidade estrutural que ele nos apresenta é absolutamente progressista.

Não se fala mais em emprego. Agora a novidade é empregabilidade, rebento nascido do cruzamento apressado do neoliberalismo com a fuga indecifrável de ativos financeiros mundo afora.

O que dizer da escola? Que feições a configuram, diante das reinvindicações que os jovens trazem de seus inconformismos? Que espécie de formação os alunos que conseguem concluir o período escolar carregam consigo para enfrentar a competição profissional e existencial? A escola paralela, patrocinada pelo tempo livre, gasto diante da televisão, dos vídeo games, das revistas, do computador, na internet, e nos quantos semilazeres do tipo, do it yourself, estabelece uma concorrência sem antecedentes à escola tradicional, emperrada no tempo e no espaço. "A sociedade dos dias de hoje permite que se destrua no tempo extra-escolar aquilo que ela constrói no tempo escolar: é como Penélope que desfazia num momento, aquilo que havia tecido num outro tempo", (DUMAZEDIER, 1994, p.74). O tempo livre, pleno de opções e equipamentos, postos à disposição de jovens e adolescentes, oferece um campo imenso de observações onde podemos compreender suas maneiras de inserção social, suas limitações, seus anseios, suas dificuldades e suas tentativas confusas de crescimento.

Haveríamos ainda de comentar sobre as rachaduras mais visíveis no campo da política, da família, e da religião, decorrentes dos abalos císmicos nelas ocorridos, tarefa que por enquanto vamos transferir para um momento futuro.

Ocupemo-nos agora de identificar e comentar algumas das mudanças de valores em nossa sociedade, interligadas ao aumento de tempo livre.

A vida íntima é um dos sinais mais contundentes da nova conformação ética hodierna. A individualidade, como valor social cresce de sentido e de reconhecimento, apesar dos ataques que recebe, ao ser considerada uma anomia ou um desengajamento social. 
"É mais precisamente uma liberação limitada no tempo de tendências longamente contidas ou reprimidas pelo peso do trabalho e das instituições normativas. Elas foram lentamente liberadas e desenvolvidas pela conquista social do tempo livre, acompanhando um nível mais elevado a ponto de permitir uma expressão social mais forte de si mesmo, através do corpo, do coração ou do espírito, não somente para alguns ociosos privilegiados mas inegavelmente para todos os trabalhadores." (DUMAZEDIER, 1994, p.48).

O sujeito social usuário do lazer de hoje não pode, nem deve ser acusado de egocentrista ou egoísta como querem alguns, já que suas atitudes respondem à sua reação em face das instituições de base que o cercam. É uma liberação pessoal, arrancada de seu interior, onde estão armazenados seus sentimentos, desejos, sonhos e aspirações anteriormente reprimidos. A sociedade de hoje se permite como nunca dantes, dar um tempo; viver por viver; ficar na sua, em determinados lapsos de tempo, sem que isso possa significar recusa às responsabilidades ou compromissos, sem que represente fuga da realidade ou omissão diante da vida.

Sonhar, esta é outra válvula de descompressão que o lazer de hoje permite ao homem, abafado por tantas regras, compromissos e uma infindável rotina.

Jogar, liberar descontraidamente repressões trazidas da infância ou da juventude, e poder soltar o corpo e a mente para reequilibrar a realidade adulta, exigente e competitiva, também é algo que o homem aprendeu a fazer ultimamente, sem sentir culpa.

É a partir da valorização eventual da individualidade, que acontece essa nova ética, plena de uma expressão mais livre, mais autêntica e mais realizadora.

Em nível grupal, semelhantemente se dá uma conduta original, típica de relações interpessoais arejadas, sem preconceitos e tabus, arrastados contumazmente de geração em geração. E, em que pese a crescente secularização da vida coletiva, provocada pelo regime da industrialização e urbanização, novas formas de reuniões sociais passaram a ocorrer. Enquanto os grupos de antigamente se reuniram basicamente em eventos religiosos, os encontros coletivos de hoje são 
provocados por instituições sócio-esportivas, sócio-profissionais, sócio-familiares, sócio-espirituais e sócio-políticas.

O calendário festivo, anteriormente marcado pela Igreja, aparece hoje cheio de novas datas cívico-sociais, e promocionais, ou ainda indicado pelas antigas datas, mas apresentado com nova roupagem e dirigido a novos interesses.

As cerimônias atuais se deixam envolver por um divertimento coletivo antes não admissível, tonando-se mais humanizadas. O tempo social era altamente ritualizado na sociedade tradicional, ao passo que nas sociedades modernas, os tempos sociais abriram-se num leque multivariável de experiências descontraídas. O rito deixa de ser prioritário em detrimento ao divertimento, que hoje é mais valorizado e enaltecido.

As reuniões ou programações familiares também espelham um comportamento renovado. Seus ritos, mais breves e leves são conduzidos por uma autoridade familiar mais democratizada e participativa, contribuindo para o progresso inquestionável da ética social do divertimento.

O grupo social denominado da terceira idade tem hoje um perfil psicológico e social revolucionário. Uma imensa vontade de viver toma conta das pessoas idosas, que não mais aceitam a velhice com passividade, nem a espera da morte com inércia e apatia.

Enfim, um cenário comportamental revisado caracteriza a sociedade pós-moderna, pintada com as cores que o lazer, fruto desta mesma sociedade, lhe impõe. Cores marcantes, mas incoerentemente não-agressivas, e muito ao contrário, de tons suaves e amenos.

\section{0 direito à preguiça ressurgente}

Quando Paul Lafargue concebeu em 1883, sua obra, o Direito à Preguiça desencadeou-se um processo revolucionário. Escrita em tom panfletário, sua repercussão adquiriu igualmente uma conotação panfletália, espalhando-se com rapidez, ecoando velozmente e gerando um imenso mal-estar, não só no ambiente objeto de sua voraz crítica, como também em meio ao círculo do qual ele fazia parte. Seu contundente desabafo, no feitio de um clamor, de um grito incontido, espalha na 
sociedade capitalista dominante uma proposta estapafúrdia, inadmissível ou impensável, em face das circunstâncias de então.

A nova ordem social imposta pela industrialização compelia os operários a trabalharem até dezesseis horas por dia, regularmente, e Paul Lafargue apregoa simplesmente a abolição radical dessa práxis. E, mais do que combater a exagerada quantidade de horas de trabalho que absorvia a mão-de-obra de mulheres e crianças em condições desumanas, ele atacava o fundamento ideológico formador da opinião capitalista que mantinha aquele status quo, que logicamente enaltecia e justificava a manutenção daquela situação. Assim, resistia ele com todas as suas forças, e reagia com ímpeto dizendo: "Na sociedade capitalista, o trabalho está na origem de toda degenerescência intelectual e de toda deformação orgânica." (LAFARGUE, 1977, p.11).

Seus agressivos disparos tinham como objetivo fazer desmoronar aquela casamata ideológica edificada pela burguesia, que propagava e exaltava o direito ao trabalho. Seus escritos eram, ao mesmo tempo, um repúdio à proposta capitalista, em razão do processo de absoluta exploração da força de trabalho disponível, e um brado de alerta dirigido ao proletariado, que sem se aperceber, e impossibilitado de reagir, vendia cegamente esta sua força de trabalho, ao bel-prazer das regras constituídas pelo capital. A preocupação de Paul Lafargue residia no fato de que os operários, suas mulheres e filhos, como que mentalmente anestesiados, não se davam conta do mecanismo que os envolvia e os escravizavam, e assinalava: "Não é um trabalho, uma tarefa, é uma tortura que se inflige a crianças entre os seis e os oito anos (...). É este longo suplício de todos os dias que sobretudo mina os operários nas fábricas de fiação de algodão", (VILLERMÉ apud LAFARGUE, 1977, p.24) e, mais adiante, conclui: "Os próprios trabalhadores, ao cooperarem na acumulação de capitais produtivos, estão a contribuir para o acontecimento que, mais tarde ou mais cedo irá privá-los de parte de seus salários", (CHERBULIEZ apud LAFARGUE, 1977, p.25).

As regras do jogo impostas pelas circunstâncias da época levavam o proletariado a correr de um lado para o outro em busca de trabalho. Dispensados, segundo as conveniências dos proprietários das fábricas, os operários saiam à caça de vagas, submetendo-se a ganhos mínimos e novamente sujeitos a serem postos na rua, sem emprego e 
sem qualquer proteção ou segurança compensatória, realimentando o sistema que só interessava e enriquecia os detentores das indústrias emergentes. Era preciso, então, ao mesmo tempo, combater esse ciclo vicioso de exploração e instruir o operariado, fazendo com que se apercebessem que as "bênçãos do trabalho" eram um engano, uma armadilha, que cada vez mais enriquecia a burguesia e tornava a massa trabalhadora mais pobre.

O pensamento dominante do autor, em sua essência, advinha do "vício pelo trabalho" ao qual o proletariado estava preso e pelo qual estava dominado. Sua apreensão era tamanha, que "LAFARGUE atacava os operários que só vivem para o trabalho, para quem a consciência profissional a serviço do patronato é a única ética, uma ética de alienação que os torna capazes de 'gozar os prazeres' que a vida nos dá ao lado do trabalho, mesmo na pobreza”, (DUMAZEDIER, 1994, p. 160).

A abstração do trabalho toma conta da humanidade, pois, paradoxalmente, a tecnologia desenvolvida em favor da produtividade, ao invés de livrar o homem do penoso fardo de horas e horas de trabalho, submete-o cada vez mais ao jugo do progresso. A máquina, inventada para benefício do homem, passa a ser um agente a mais a explorá-lo. A denúncia é clara:

"Uma boa operária faz com um fuso apenas cinco malhas por minuto, certos teares circulares de tricotar fazem trinta mil no mesmo espaço de tempo. Cada minuto da máquina equivale, pois, a cem horas de trabalho da operária; ou então cada minuto de trabalho da máquina proporciona à operária dez dias de descanso. O que acontece com a indústria de malhas acontece, mais ou menos, com todas as indústrias renovadas pela mecânica moderna. Mas que vemos nós? À medida que a máquina se aperfeiçoa e reduz o trabalho do homem com uma rapidez e uma precisão cada vez maiores, o operário, em vez de prolongar outro tanto o seu descanso, redobra de ardor, como se quisesse rivalizar com a máquina. Oh! que concorrência absurda e assassina!" (LAFARGUE, 1977, p.31).

A máquina passa a concorrer com o homem, ao invés de a ele beneficiar, e quanto mais tecnologia, mais trabalho. Para tanto, os dias 
feriados foram gradativamente sendo suprimidos e, em consequiência, o tempo livre, o descanso e o divertimento foram igualmente diminuídos. As leis religiosas garantiam ao trabalhador noventa dias de descanso, compostos de cinquienta e dois domingos e trinta e oito feriados, durante os quais era absolutamente proibido o trabalho. A Revolução Industrial, em nome da tecnologia e do progresso, quase destruiu por completo essa milenar lei.

Recorramos agora a Domenico De Masi para aprofundarmos melhor esta questão:

"Milhares de anos foram necessários para domesticar o cão que puxa o trenó e para dominar o fogo necessário para cozinhar os alimentos e se defender do frio. Outros milênios foram necessários para lançar a flecha com um arco, concentrando o máximo empuxo num só ponto e num só momento. Há 10.000 anos a mulher pela primeira vez trabalhou na agricultura e o homem experimentou o pastoreio. Na Mesopotâmia de 5.000 anos atrás, nasceram o eixo da roda, a astronomia, a matemática e a escultura." (DEMASI, 1993, p.40).

Apoiados no raciocínio desse autor vamos aprofundar a reflexão: para o homem da antiguiidade ter alcançado os progressos acima citados era algo tão desconsertante que Aristóteles afirmou que tudo o que se podia pensar, no sentido de dar ao homem uma vida cotidiana mais fácil e cômoda, já tinha sido descoberto. Assim, nada mais cabia fazer senão dedicar-se por inteiro ao espírito.

Então, acomodados nessa sua convicção, gregos e romanos, cercados de uma enorme quantidade de escravos, pouco fizeram para que a humanidade auferisse progressos significativos, na ciência e na tecnologia.

Como afirma Domenico de Masi, eram 300.000 escravos para 50.000 cidadãos livres; na Roma Antiga, no ápice de seu poderoso império, havia com 10 milhões de escravos, ou seja, a população livre era cerca de vinte por cento da população de escravos de então.Não obstante, afirma Domenico de Masi:

"Quando na Idade Média os escravos começaram a rarear, os nossos antepassados se lembraram das oportunidades ofereci- 
das pela tecnologia e desfrutaram rapidamente das inovações. $\mathrm{O}$ moinho de água e vento, o estribo e os arreios, a roca de fiar, a rotação das culturas agrícolas, os óculos, a pólvora, o relógio mecânico, a bússola e a imprensa permitiram substituir a força humana pela inorgânica e anteciparam a grande arrancada do pensamento que levaria ao iluminismo e à revolução industrial. Foi no final do século XIV que Bacon, prevendo o salto tecnológico que a humanidade estava para efetuar, inverteu o pensamento de Aristóteles e no seu tratado Instauratio Magna afirma que tudo o que se podia fazer pela elevação do espírito já tinha sido feito pelos gregos e pelos romanos: nada restava senão se dedicar à filosofia das obras, à aplicação do intelecto às coisas concretas, ao progresso da indústria para melhorar finalmente a vida prática do dia-a-dia" (DE MASI, 1993, p.42).

Foi em decorrência desse novo pensamento que a Revolução Industrial surge e impõe drasticamente uma nova ordem social. Foi um salto muito grande em tão pouco tempo. Da Europa de Julio César até a Europa de Napoleão, quase dezoito séculos foram necessários, e o progresso científico não foi considerável. Longe disso, foi quase insignificante diante da explosão tecnológica desencadeada pela construção das fábricas, dos teares e de outras tantas máquinas capazes de substituir o trabalho manual humano.

Utilizando-se da tecnologia mecânica, a vapor e elétrica, esta sociedade industrial recém-nascida, cresce multiplicando o saber teórico e prático, científico e artístico. As novidades se desdobram em outras tantas novidades como ondas que se propagam, e novamente se desdobram em outras descobertas e invenções, cada vez mais avançadas. Enveredamos pelo mundo da biociência e chegamos ao clone de animais, e para chegarmos ao clone humano basta vencer a barreira da ética, o maior dos empecilhos que limita tal façanha. A sociedade préindustrial venceu barreiras, construiu a sociedade industrial e agora gera a sociedade pós-industrial, capaz de produzir bens materiais, simbólicos, abstratos.

O desencadear do conhecimento é tão grande, que em quatro décadas se chegou a mais progresso que nos últimos quarenta mil anos anteriores. A população mundial no fim deste século é doze vezes mais do que na época de Isaac Newton e nossa vida média, de 700.000 horas 
(cerca de 80 anos) é seis vezes mais longa que a do homem de Neanderthal, e mais que o dobro dos cerca de 35 anos médios de nossos avós. Eles trabalhavam em torno de 120.000 horas enquanto nós, 80.000 . Nossos filhos, com uma expectativa média de vida projetada para cerca de 900.000 horas, ou 102,7 anos, não trabalharão mais do que 50.000 horas.

Previsões para as próximas décadas apontam para o crescimento do nível de conhecimento, cobrindo a escola pelo menos os vinte primeiros anos do cidadão. Os meios de comunicação se expandirão bem mais do que os níveis alcançados até hoje, graças à crescente miniaturização dos componentes eletrônicos e o barateamento da tecnologia digital. Teremos um aumento considerável da qualidade existencial de nossas vidas, com a maximização da lucidez mental, destreza do corpo e capacidade profissional. A descoberta de novos remédios, não só possibilitará o adiamento da morte, como a minimização dos processos dolorosos das doenças e contribuirão ainda mais para que essa qualidade existencial se concretize.

Em contrapartida a toda essa colossal metamorfose, a humanidade terá que se reciclar para poder se adaptar a tantas mudanças, passando por radicais reestruturações nos seus perfis políticos, sociais e psicológicos. Nesses aspectos, não estamos preparados para as exigências do mundo pós-industrial, e espera-se uma dose bem grande de esforço, sofrimento e determinação para se alcançarem tais ajustes.

A expectativa é a de uma revolução, como já comentamos anteriormente, que vem modificando os costumes, e costurando um novo feitio de sociedade, afetada e condicionada pelas mudanças profundas que vêm acontecendo no mundo do trabalho, não só pelas novas regras da empregabilidade, nascidas pela ação perversa do neoliberalismo, como e principalmente pela reação silenciosa que os trabalhadores do terceiro milênio já estão impondo.

Nesta mesma linha de pensamento nos auxilia De Masi, ressaltando:

"Em contraponto aos valores da arrancada industrial, todos centrados no empirismo, no racionalismo, no consumismo - traduzidos no imaginário da posse, poder e da riqueza - emergem valores novos, voltados mais para a criatividade, estética, confiança, subjetividade, feminilização, afetividade, desestruturação do tempo e do espaço, qualidade de vida" (DE MASI, 1993, p.45). 
Isso tudo, sem dúvida implica um novo padrão de bem-estar a ser reinventado. O homem do ano 2000 anseia por uma nova forma de tempo livre. Necessário se faz reencantá-lo.

Um teste prático e desafiador diante de nossos olhos é o desemprego que alcança índices cada vez mais preocupantes. Há uma crescente expectativa de que a evolução tecnológica irá, cada vez mais, limitar o trabalho humano, quer físico, quer mental, cabendo ao homem o espaço das funções criativas, enquanto às máquinas, a produção.

A grande e inquietante questão é: O que restará à grande massa, enquanto a uns poucos couber a tarefa do criar? Aqueles, a quem couberem trabalhos secundários, como poderão ser remunerados? Que ordem motivacional se incumbirá de reger a sociedade pós-industrial? Eé o próprio Domenico De Masi que oferece uma pista a ser investigada.

"A humanidade espera com volúpia novas descobertas: substâncias para debelar definitivamente a dor, sistemas para acabar com o lixo radioativo transformado em matérias inócuas, novas fontes de energia, técnicas adequadas para eliminar o barulho e a fome e reabsorver a poluição. Paralelamente, nunca tivemos tantas ferramentas para eliminar as quatro escravidões da escassez, da tradição, do autoritarismo e do cansaço físico. Continuamos hoje lutando contra essas escravidões.

Aristóteles, citado várias vezes porque é o pai da cultura ocidental, sonhava: se cada ferramenta pudesse, a partir de uma ordem dada, trabalhar por conta própria, se os teares tecessem sozinhos, se o arco tocasse, sozinho nas cordas da cítara, então os empreendedores poderiam privar-se dos operários e os proprietários, dos escravos. Nunca, como hoje, estivemos tão perto da realização desse sonho: fábricas inteiramente automatizadas já estão em operação em três dos cinco continentes. O mito de Sísifo pode finalmente ser reescrito.

Como se sabe, o herói grego foi punido pelos deuses por excesso de engenhosidade. Segundo a explicação clássica, tendo ele cometido um pecado intelectual, foi punido em compensação com uma pena material: transportar por toda a eternidade uma rocha até o topo de um monte e, quando ela precipitava de novo até a base, tornar a pegá-la e lavá-la outra vez até o alto do monte. Em plena sociedade industrial, o escritor francês Albert Camus reinterpretou esse mito: sendo Sísifo um intelectual, o 
seu verdadeiro sofrimento não se consumava na subida, quando a sua mente estava toda ocupada pelo esforço sobre-humano de transportar a rocha até o topo. O seu verdadeiro sofrimento era quando, com a pedra mais uma vez no alto do monte, Sísifo tinha que descer a escarpada e, sem nenhum esforço, tinha toda a trágica consciência de ter sido condenado pela crueldade dos deuses a um trabalho inútil e sem esperança.

Para nós, homens pós-industriais, há uma terceira alternativa. Sísifo vai construir um mecanismo eletrônico ao qual delegará a canseira do transporte inútil e banal e se sentará no alto do morro para contemplar o seu robô em função, saboreando enfim a felicidade do ócio prazeroso “(DE MASI, 1993, p.47).

No entanto, permanece a inquietação: até quando o contemplar do robô não irá se transformar em tédio novamente e qual será o próximo desejo capaz de satisfazer a angústia por um lazer definitivo?

Ao expor sua conferência: A ditadura do tempo abstrato sobre a crise comparativa de trabalho e lazer, Robert Kurz (1998) talvez esteja apontando para uma presumível resposta, que sem dúvida não dá um ponto final à questão, mas parece uma trilha bastante desafiante a ser seguida.

Sustenta ele, que a sociedade contemporânea vive sob o estigma de uma insatisfação permanente, mascarada pela perspectiva de um tempo livre inalcançável. Segundo Kurz, a modernidade capitalista assegura para si a responsabilidade de ter oferecido o progresso, considerando o passado pré-moderno como um tempo de miséria, de fome, de escravidão e trabalho pesado. Mas, na realidade, desde o século XVI q esta modernidade capitalista criou as jornadas exaustivas de trabalho, levando a classe trabalhadora a ultrapassar limites de sua capacidade física suportável. Foi a muito custo e após renhidas lutas sociais, que a jornada de trabalho foi gradativamente reduzida, no final do século passado.

As sociedades pré-modernas não conheciam:

"A abstração do trabalho ou o termo designava uma atividade em estado de dependência ou de não emancipação. Metaforicamente, portanto, o trabalho significava sofrimento e desgraça. Por outro lado, não existia designação geral para as atividades concretas no "processo de metabolismo com a natureza (MARX) da produção agrícola até a arte.” (KURZ, 1998, p.46). 
Dessa forma, o dinheiro passou da condição de meio para fim abstrato, e à medida que as atividades resultantes da produção passaram a ter como referência um bem abstrato (o dinheiro abstrato), o trabalho passou a ser uma ação igualmente abstrata. Cria-se um ciclo vicioso automático: à medida que a transmutação de dinheiro exige mais dinheiro, o trabalho implica mais trabalho.

Assim, segundo o mesmo raciocínio, o tempo de trabalho se transformou num tempo abstrato, conforme aponta Robert Kurz (1998, p.46):

"Essa ditadura do tempo abstrato, incrementada pela conconrência anônima, transformou as atividades do 'processo de metabolismo com a natureza' em espaço funcional abstrato, ou seja, o capital divorciado do restante da vida. Assim sendo, dissociaramse 'trabalho' e moradia, 'trabalho' e vida íntima, 'trabalho' e cultura, etc. Foi apenas desta forma que também surgiu a moderna separação e o dualismo entre 'trabalho' e 'lazer'.

Nas sociedades pré-modernas, ainda que se dispondo de parcos recursos, a finalidade da produção não consistia em finalidade abstrata em si, mas sim em fruição e ócio (lazer). Não podemos confundir esta noção antiga e medieval de ócio com o lazer moderno. O ócio não era uma fração de vida isolada do processo de atividade com fins lucrativos, mas estava presente até nos poros e nichos da própria atividade produtiva. Em termos atuais, é por este motivo que a jornada de trabalho não era apenas mais curta, como ainda menos concentrada."

A sociedade moderna, como tivemos oportunidade de ressaltar anteriormente, não tem feito outra coisa nestes últimos tempos, que não, buscar tecnologia que torne a vida mais fácil. Como consequiência deveria conquistar uma jornada de trabalho menor, com excedente de tempo livie maior.

O que se verifica, no entanto, é que a jornada real de trabalho foi muito pouco reduzida em relação aos enormes ganhos de produtividade que a tecnologia tem permitido. Mas, a frustração maior em relação ao ganho de tempo livre está nos termos do próprio conteúdo que este tempo traz consigo.

"Na medida em que aumentou realmente este mero restante da vida, ele foi imediatamente ocupado pela finalidade própria do 
capital: a indústria da cultura e a indústria do lazer passaram a ocupar e a colonizar o tempo penosamente conquistado e concedido fora do espaço funcional abstrato. Uma vez que o 'trabalho' carece, a priori, de emancipação, o 'lazer' também tem de ser dependente. Não consiste em um tempo liberado, pois que se transforma em espaço funcional secundário do capital. Não se trata, portanto, de ócio livre, no sentido antigo, mas de tempo funcional para o consumo permanente de mercadorias. Ironicamente, o lazer tornou-se para o consumidor a continuação do trabalho por outros meios. Não apenas quando "ganha" dinheiro, mas também quando o gasta, o homem capitalista é um 'trabalhador'. A ditadura do tempo abstrato também ocupou o lazer (KURZ, 1998, p.46)."

Ao darmos termos finais a este artigo, conjuntando o centenário pensamento de Lafargue com as recém-nascidas reflexões de De Masi e Kurz, merece crédito a idéia de que, segundo a qual, de fato, o homem anseia por resgatar um tempo perdido, ou melhor, uma determinada forma de Tempo Livre perdido, confiscado que lhe foi pelo progresso, pela divisão racional do trabalho, pela falácia da tecnologia.

Quase que como em busca do paraíso perdido, tão amplamente explorado nas obras de ficção, a sociedade pós-moderna está em busca de um lazer pleno, cabal, quem sabe o ócio prazeroso, do Sísifo do século XXI. Quem sabe um lazer híbrido, daqueles gerados em laboratório, como sementes resultantes do cruzamento genético de inúmeras espécies, mas ao mesmo tempo nascido de componentes que emerjam do mais íntimo do ser humano, coletados nas suas entranhas, que responda às suas reais necessidades, e que certamente até o momento não foi inventado.

Para o reduzido número de afortunados que são capazes de um maior controle do seu próprio ritmo de vida a ruptura entre lazer e trabalho está começando a se tornar menos nítida. Para estes, empresários bem sucedidos, profissionais autônomos, artistas, poetas, "não existe a dicotomia lazer/trabalho como o correspondente da dicotomia prazer/ dor. Essas duas noções se embaralham e seus limites perdem a nitidez" (FORJAZ, 1988, p.101). Talvez aí esteja nascendo uma nova pista, uma opção inusitada.

O grito de Paul Lafargue, aparentemente abafado, ainda ecoa, e sua proposta paira no ar. Como uma profecia prestes a ser cumprida, ele 
está de volta, conspirando contra valores aparentemente inabaláveis. E, apesar de inúmeros ajustes até agora conquistados, apesar de todos os fugazes arranjos até recentemente implementadas, algo de novo está por acontecer, capaz de restituir ao homem a satisfação, que ele espera, quando se trata de lazer. É o Direito à Preguiça ressurgente.

É preciso, pois, reinventar o lazer, e para tanto é possível que se tenha que reinventar a escola, o trabalho e outras instituições de base da sociedade, quitando-se com ela uma antiga dívida, restituindose ao homem atual a perspectiva de uma vida em plenitude, que há um tempo não tão remoto já foi experimentada pelo homem original. 


\section{Referências Bibliográficas}

CAMARGO, Luiz O. de Lima. O que é lazer? 2.ed. São Paulo; Brasiliense, 1977.

DE MASI, Domenico. Em busca do ócio. Veja, São Paulo, edição comenorativa dos 25 anos de Aniversário, p.40-49, set. 1993.

DUMAZEDIER, Joffre. A Revolução Cultural do Tempo Livre. São Paulo: Estúdio Nobel. Sesc, 1994.

- Sociologia Empírica do Lazer. São Paulo: Perspectiva, 1974.

Lazer e Cultura Popular. São Paulo: Perspectiva, 1976.

FORJAZ, Maria Cecilia Spina. Lazer e consumo cultural das elites. Revista Brasileira de Ciências Sociais, v.3, n.6, p.101, fev., 1998.

LAFARGUE, Paul. O Direito à Preguiça. Lisboa: Editorial Teorema, 1977.

KURZ, Robert. A ditadura do tempo abstrato sobre a crise comparativa de trabalho e lazer. In: CONGRESSO MUNDIAL DE LAZER, 5., São Paulo, 1998. Programa... São Paulo, 1998. p.46

PARKER. Stanley. A Sociologia do Lazer. Rio de Janeiro: Zahar. 1978.

\section{Abstract}

The study of leisure, in this article, aims at investigating conceptually this social phenomenon, which is in high evidence and becoming each day an object of use and practice. Moreover, because of the changes leisure has been through, especially in the last few years, many studies have it as a culmination point of transition towards the new millennium. From the economical point of view, leisure is also a segment which has been growing worldwide, due to the complexities and potentialities it implicates, it has been propitiating one of the biggest changes ever seen along the history.

Key-words: work; leisure; industrial revolution. 